\title{
A Computational Growth Framework for Biological Tissues: Application to Growth of Aortic Root Aneurysm Repaired by the V-shape Surgery
}

\author{
Hai Dong ${ }^{1}$, Minliang Liu ${ }^{1}$, Tongran Qin ${ }^{1}$, Liang Liang ${ }^{2}$, Bulat Ziganshin ${ }^{3}$, Hesham Ellauzi ${ }^{3}$, \\ Mohammad Zafar ${ }^{3}$, Sophie Jang ${ }^{3}$, John Elefteriades ${ }^{3}$, Wei Sun ${ }^{1}$, Rudolph L. Gleason Jr ${ }^{1}$ \\ ${ }^{1}$ The Wallace H. Coulter Department of Biomedical Engineering \\ Georgia Institute of Technology and Emory University, Atlanta, GA; \\ ${ }^{2}$ Department of Computer Science, University of Miami, Coral Gables, FL; \\ ${ }^{3}$ Aortic Institute at Yale-New Haven Hospital, \\ Yale University School of Medicine, New Haven, CT
}

Submitted to

Journal

$9 / 30 / 2021$

\section{For correspondence:}

Rudolph L. Gleason Jr, Ph.D.

The Wallace H. Coulter Department of Biomedical Engineering

Georgia Institute of Technology and Emory University

Technology Enterprise Park, Room 204

387 Technology Circle, Atlanta, GA 30313-2412

Tel:(404) 385-7218; Email: rudy.gleason@me.gatech.edu 
medRxiv preprint doi: https://doi.org/10.1101/2021.09.30.21264318; this version posted October 1, 2021. The copyright holder for this preprint (which was not certified by peer review) is the author/funder, who has granted medRxiv a license to display the preprint in perpetuity.

All rights reserved. No reuse allowed without permission.

\section{Abstract}

Ascending aortic aneurysms (AsAA) often include the dilatation of sinotubular junction (STJ) which usually leads to aortic insufficiency. The novel surgery of the V-shape resection of the noncoronary sinus, for treatment of AsAA with root ectasia, has been shown to be a simpler procedure compared to traditional surgeries. Our previous study showed that the repaired aortic root aneurysms grew after the surgery. In this study, we developed a novel computational growth framework to model the growth of the aortic root repaired by the V-shape surgery. Specifically, the unified-fiber-distribution (UFD) model was applied to describe the hyperelastic deformation of the aortic tissue. A novel kinematic growth evolution law was proposed based on existing observations that the growth rate is linearly dependent on the wall stress. Moreover, we also obtained patient-specific geometries of the repaired aortic root post-surgery at two follow-up time points (Post1 and Post2) for 5 patients, based on clinical CT images. The novel computational growth framework was implemented into the Abaqus UMAT user subroutine and applied to model the growth of the aortic root from Post 1 to Post2. Patient-specific growth parameters were obtained by an optimization procedure. The predicted geometry and stress of the aortic root at Post2 agree well with the in vivo results. The novel computational growth framework and the optimized growth parameters could be applied to predict the growth of repaired aortic root aneurysms for new patients and to optimize repair strategies for AsAA.

Keywords: Aortic root aneurysm; Growth and remodeling; V-shape surgery; Unified-fiberdistribution (UFD) model 
medRxiv preprint doi: https://doi.org/10.1101/2021.09.30.21264318; this version posted October 1, 2021. The copyright holder for this preprint (which was not certified by peer review) is the author/funder, who has granted medRxiv a license to display the preprint in perpetuity.

All rights reserved. No reuse allowed without permission.

\section{Introduction}

Aortic aneurysms are critical conditions that frequently require surgical intervention to prevent dissection, rupture, and death [1-4]. Ascending aortic aneurysms (AsAA) often include the dilatation of sinotubular junction (STJ) and extend proximally into the the aortic root, which usually leads to aortic insufficiency [5, 6]. Recently, Elefteriades et al. [7] reported a simpler Vshape resection technique of the noncoronary sinus intended for infirm or elderly patients with AsAA and root ectasia. This simple, quick procedure addresses the aortic root dilatation without the complexities of full aortic root surgery with coronary button reimplantation [7]. In our previous study, we showed [8] that there is significant reduction in the wall stress of the aortic root repaired by the V-shape surgery. The results also indicated that the aortic root could grow after the V-shape surgery. It will be beneficial to model the growth of the aortic root aneurysm after surgery for growth prediction of new patients.

A number of studies have investigated the growth and remodeling (G\&R) of aortic aneurysms. For instance, Lin et al. [9] studied the formation and dilatation of abdominal aortic aneurysms with a mixture theory of growth and remodeling. Mousavi et al. [10] predicted the aneurysm growth and remodeling in the ascending thoracic aorta using the homogenized constrained mixture model. Ghavamian et al. [11] studied of growth and remodeling in ascending thoracic aortic aneurysms considering variations of smooth muscle cell basal tone. Farsad et al. [12] investigated the effect of the spine constraint for progression of the abdominal aortic aneurysms using a membrane G\&R model. However, few existing studies have modelled the growth and remodeling of aortic aneurysms with follow-up clinical images for patient-specific geometries. 
medRxiv preprint doi: https://doi.org/10.1101/2021.09.30.21264318; this version posted October 1, 2021. The copyright holder for this preprint (which was not certified by peer review) is the author/funder, who has granted medRxiv a license to display the preprint in perpetuity.

All rights reserved. No reuse allowed without permission.

The constrained mixture model [13] and the kinematic/finite growth model [14] are two leading approaches for growth and remodeling of soft tissues. The constrained mixture model, proposed by Humphrey and Rajagopal [13], considers the kinetics of the production and removal of individual constituents and has been widely used to model the growth and remodeling of soft tissues including myocardial hypertrophy [15], tendon healing [16], and growing tumor [17]. The kinematic/finite growth model, developed by Rodriguez et al. [14], separates the total deformation into an elastic part and a growth part, and has also been extensively applied in growth and remodeling of soft tissues. For instance, Eskandari et al. [18] studied the patient-specific airway wall remodeling in chronic lung disease by the kinematic growth model. Soleimani et al. [19] developed a stress-induced anisotropic growth model driven by nutrient diffusion based on the finite/kinematic growth approach. The kinematic growth approach is appropriate for studies that do not quantify changes in the content and organization of individual constituents, as is often the case in studies that rely solely on non-invasive measurements.

In this paper, we developed a novel computational framework with the kinematic growth approach for the growth of the aortic root following repaired by the V-shape surgery. The unifiedfiber-distribution (UFD) model [20] was applied to describe the hyperelastic deformation of the aortic tissue. A novel kinematic growth evolution law was proposed based on existing observations that the growth rate is approximately linearly dependent on the principal components of in-plane wall stress. The novel computational growth framework was implemented into the Abaqus UMAT user subroutine and applied to model the growth of the aortic root aneurysm repaired by the Vshape surgery, based on patient-specific follow-up geometries reconstructed from in vivo CT images. Patient-specific growth parameters were obtained from the first four patient data sets by an optimization procedure. The growth framework, using the average growth parameters from the 
first four patients, were compared to the follow-up geometries of the fifth patient to assess the predictive capability of the model and fitted parameters. The wall stress of the aortic root was also investigated.

Table 1: Patient information: Gender, systolic pressure, diastolic pressure, and time interval $\left(\Delta \mathrm{T}_{12}\right)$ between the two follow-up time points post-surgery (Post1 and Post2).

\begin{tabular}{|c|c|c|c|c|}
\hline Patient ID & Gender & $\begin{array}{c}\text { Systolic Pressure } \\
(\mathrm{mmHg})\end{array}$ & $\begin{array}{c}\text { Diastolic Pressure } \\
(\mathrm{mmHg})\end{array}$ & $\begin{array}{c}\Delta \mathrm{T}_{12} \\
(\mathrm{month})\end{array}$ \\
\hline P1 & $\mathrm{F}$ & 123 & 92 & 20 \\
\hline P2 & $\mathrm{M}$ & 140 & 79 & 43 \\
\hline P3 & $\mathrm{M}$ & 125 & 82 & 24 \\
\hline P4 & $\mathrm{M}$ & 120 & 62 & 52 \\
\hline P5 & $\mathrm{M}$ & 120 & 80 & 22 \\
\hline
\end{tabular}

\section{Methods}

\subsection{Construction of Patient-Specific Finite Element Model}

Clinical CT images of the aortic root at two follow-up time points post-surgery were obtained for 5 patients (P1-P5) who underwent the surgery of the V-shape resection of the noncoronary sinus [7], at Yale-New Haven Hospital, New Haven, Connecticut. The CT image of the first time point (Post1) was obtained within 4 months after the surgery. The time interval between the second time point (Post2) and Post1 ranged from 20 months to 52 months. The patient demographic information is provided in Table 1. The in-plane spatial resolution of the CT images was between $0.37 \times 0.37 \mathrm{~mm}$ and $0.96 \times 0.96 \mathrm{~mm}$, with the slice thickness ranging from 0.30 to $1.00 \mathrm{~mm}$. The details of the CT images resolution for each patient can be found in the Appendix. All human subjects in this study provided written and informed consent, and IRB approvals were 
medRxiv preprint doi: https://doi.org/10.1101/2021.09.30.21264318; this version posted October 1, 2021. The copyright holder for this preprint (which was not certified by peer review) is the author/funder, who has granted medRxiv a license to display the preprint in perpetuity.

All rights reserved. No reuse allowed without permission.

obtained from Georgia Tech Institutional Review Board (\#H20373, 10/13/2020) and Yale University Human Investigation Committee (\#0109012617, 06/29/2020).

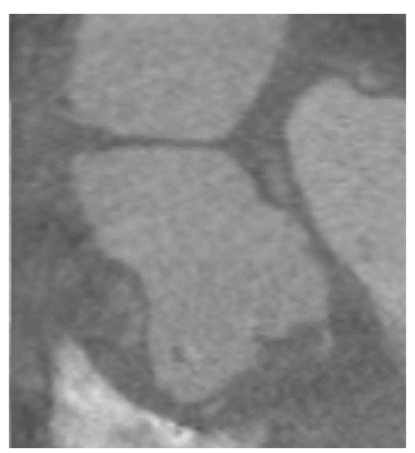

(a)

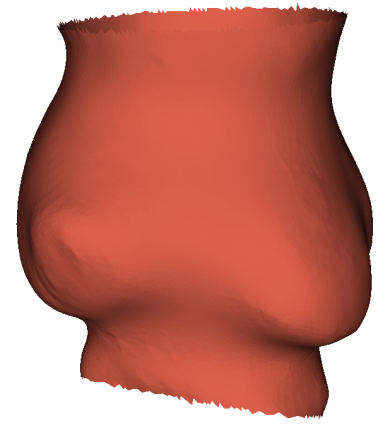

(b)

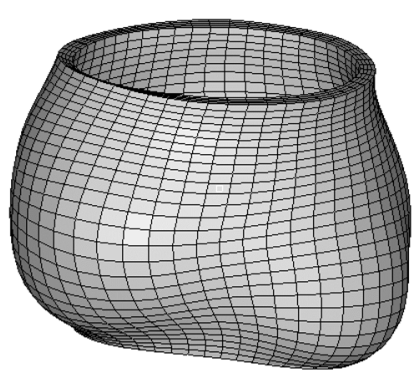

(c)

Fig 1. (a) CT image of the aortic root of a representative patient (P1) post-surgery; (b) 3D surface geometry of the aortic root reconstructed based on CT in (a) using 3D Slicer (www.slicer.org); (c) Finite element mesh generated in HyperMesh 2017 (Altair Engineering) based on the geometry in (b) with trimmed boundaries.

Based on the CT images (e.g., Fig. 1a), the three-dimensional (3D) surface geometry (Fig. 1b) of the aortic root was reconstructed using 3D Slicer (www.slicer.org). The surface geometry was exported out from the 3D Slicer and imported into Altair HyperMesh 2017 (Altair Engineering) to generate the finite element mesh for the aortic root (Fig. 2c). We first created 4-node quadrilateral shell elements (S4) with element size of about $1.5 \mathrm{~mm}$ by $1.5 \mathrm{~mm}$ based on the surface geometry. Four layers of eight-node linear brick elements (C3D8) were created by offsetting the S4 elements [21, 22]. A total thickness estimate of $1.5 \mathrm{~mm}$ was applied to the aortic wall following Liu et al. [23], since the accurate thickness of the aortic wall is not available from the CT images. The finite element mesh of the aortic root of Post1 and Post2 for the 5 patients were obtained. Analysis of mesh size independence was performed. 
medRxiv preprint doi: https://doi.org/10.1101/2021.09.30.21264318; this version posted October 1, 2021. The copyright holder for this preprint (which was not certified by peer review) is the author/funder, who has granted medRxiv a license to display the preprint in perpetuity.

All rights reserved. No reuse allowed without permission.

\subsection{Growth Framework based on the Unified-Fiber-Distribution Model}

Following Rodrigue et al. [14], we assumed that the total deformation gradient of the tissue can be decomposed multiplicatively into an elastic part and a growth part (Fig. 2),

$$
\mathbf{F}=\mathbf{F}_{e} \mathbf{F}_{g}
$$

where $\mathbf{F}_{g}$ is the deformation gradient from the original reference state to the current reference state due to tissue growth, and $\mathbf{F}_{e}$ is the elastic deformation gradient from the current reference state to the current loaded state due to the mechanical loading. The constitutive model for the relation between the elastic deformation $\mathbf{F}_{e}$ and the loading was described by our recently developed unified-fiber-distribution (UFD) model [20] which considers the fiber distribution as a whole distribution without separating it into multiple fiber families. The evolution of the growth deformation $\mathbf{F}_{g}$ was described by a newly proposed growth evolution law based on the assumption that the tissue growth was governed by the in-plane principal components of Cauchy stress.

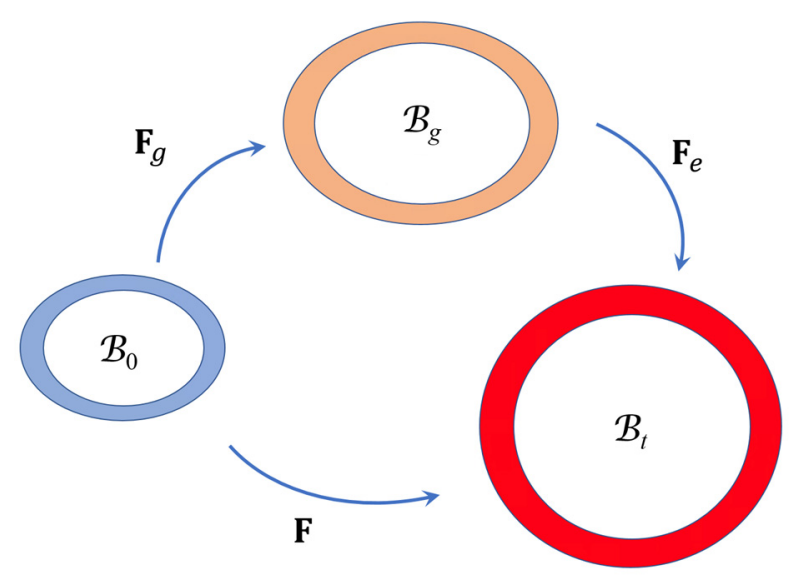

Fig 2. Schematic of the multiplicative decomposition of the total deformation gradient $\mathbf{F}$ into an elastic part $\mathbf{F}_{e}$ and a growth part $\mathbf{F}_{g} . \mathcal{B}_{0}$ represents the reference configuration, $\mathcal{B}_{g}$ is the growth configuration and $\mathcal{B}_{t}$ denotes the current configuration under inner pressure loading. 
medRxiv preprint doi: https://doi.org/10.1101/2021.09.30.21264318; this version posted October 1, 2021. The copyright holder for this preprint (which was not certified by peer review) is the author/funder, who has granted medRxiv a license to display the preprint in perpetuity.

All rights reserved. No reuse allowed without permission.

\subsubsection{Unified-Fiber-Distribution (UFD) Hyperealstic Model}

Aortic walls are usually composed of three layers, the intima, media and adventitia layers [24]. The tissue of each layer is comprised of networks of collagen fibers embedded in a ground matrix and can be regarded as fiber reinforced composites, of which the mechanical properties are anisotropic [25-27], similar to engineering fiber-reinforced composites [28-32]. Schriefl at al. [33] showed that there are significant dispersions for the collagen fiber distributions in the three layers of human arteries, and each layer may contain multiple fiber families. Their study [33] also revealed that the number of fiber family may vary from different positions for the same kind of tissue, such as there are two fiber families in the media of human descending thoracic aorta and abdominal aorta, while there is only one fiber family in the media of common iliac artery. Previously, we developed a unified-fiber-distribution (UFD) model [20] which considers the fibers as a unified distribution and thus the number of fiber families is not necessary as it is in the widely used Gasser-Ogden-Holzapfel (GOH) model [34]. The later usually reduces a general fiber distribution into two fiber families, which may be not consistent with the real fiber distribution of aortic tissues. Here, the UFD model was applied to characterize the hyperelastic deformation of the aortic tissues.

The total strain energy function can be decomposed additively into an isochoric part and a volumetric part

$$
\Psi=\Psi_{\mathrm{iso}}+\Psi_{\mathrm{vol}}
$$

where the volumetric part is given by $\Psi_{\text {vol }}=\frac{1}{D}(J-1)^{2}$ with $D$ to be a material constant which is used to enforce incompressibility of the tissue, based on the assumption that the aortic tissue is approximately incompressible. The isochoric part can be further expressed as 


$$
\Psi_{\text {iso }}=\Psi_{m}+\Psi_{f}
$$

where $\Psi_{m}$ is the strain energy of the matrix contribution given by the neo-Hookean model [35-39]

$$
\Psi_{m}=\frac{1}{2} c\left(\bar{I}_{1 e}-3\right)
$$

where $c$ is the initial shear modulus of the matrix, $\bar{I}_{1 e}=\operatorname{tr}\left(\overline{\mathbf{C}}_{e}\right)$ is the first invariant of $\overline{\mathbf{C}}_{e}=$ $J_{e}^{-2 / 3} \mathbf{C}_{e}$, with $\mathbf{C}_{e}=\mathbf{F}_{e}^{T} \mathbf{F}_{e}$ denoting the right Cauchy-Green tensor and $J_{e}=\operatorname{det} \mathbf{F}_{e}>0$ is the determinant of the deformation gradient $\mathbf{F}_{e}$. The $\Psi_{f}$ is the strain energy of the fiber contribution which distinguishes the UFD model from other models, given by [20]

$$
\Psi_{f}=\frac{k_{1}}{2 k_{2}}\left[\exp \left\{k_{2}\left[\delta_{\|}(1-\zeta)^{2}\left(\bar{I}_{4 e}-1\right)^{2}+\delta_{\perp} \zeta^{2}\left(\bar{I}_{4 e \perp}-1\right)^{2}\right]\right\}-1\right]
$$

where $\bar{I}_{4 e}=\left(\mathbf{a}_{0} \otimes \mathbf{a}_{0}\right): \overline{\mathbf{C}}_{e}$, and $\bar{I}_{4 e \perp}=\left(\mathbf{a}_{0 \perp} \otimes \mathbf{a}_{0 \perp}\right): \overline{\mathbf{C}}_{e}$ with $\mathbf{a}_{0}$ and $\mathbf{a}_{0 \perp}$ denoting the unit vectors in the circumferential (mean-fiber) direction and the axial (cross-mean-fiber) direction, respectively. The parameters $k_{1}, k_{2}$ and $\zeta$ are fiber related material parameters with $k_{1}$ representing the initial stiffness, $k_{2}$ representing the stiffening effect under stretch, and $\zeta$ is a scalar characterizing the fiber distribution in an integral sense. The role of $\delta_{\|}$and $\delta_{\perp}$ is to exclude the contribution of the compressed fibers, given by the Heaviside step function

$$
\delta_{\|}=H\left(\bar{I}_{4 e}-1\right)=\left\{\begin{array}{l}
1 \text { if } \bar{I}_{4 e} \geq 1 \\
0 \text { if } \bar{I}_{4 e}<1
\end{array}, \delta_{\perp}=H\left(\bar{I}_{4 e \perp}-1\right)=\left\{\begin{array}{ll}
1 & \text { if } \bar{I}_{4 e \perp} \geq 1 \\
0 & \text { if } \bar{I}_{4 e \perp}<1
\end{array} .\right.\right.
$$

The material parameters of the UFD model applied in this study are summarized in Table 2.

Table 2. The parameters used in the UFD model. The $R^{2}$ describes the goodness of the fit based on the experiments [40].

\begin{tabular}{|c|c|c|c|c|c|c|}
\hline Parameters & $c(\mathrm{kPa})$ & $k_{1}(\mathrm{kPa})$ & $k_{2}(-)$ & $\zeta(-)$ & $D\left(\mathrm{kPa}^{-1}\right)$ & $R^{2}$ \\
\hline Values & 222.07 & 101.81 & 99.99 & 0.46 & $1 \times 10^{-6}$ & 0.93 \\
\hline
\end{tabular}




\subsubsection{Growth Evolution Law}

We assumed the growth deformation $\mathbf{F}_{g}$ in Eq. (1) can be expressed as

$$
\mathbf{F}_{g}=\left[\begin{array}{ccc}
v_{1} & 0 & 0 \\
0 & v_{2} & 0 \\
0 & 0 & v_{3}
\end{array}\right]
$$

where $v_{1}, v_{2}$ and $v_{3}$ are the growth stretch multipliers. The directions $\{1,2,3\}$ represent the principal directions of the local Cauchy stress. For a cylindrical tube under inner pressure loading, the directions $\{1,2,3\}$ represents the circumferential, axial and radial directions, respectively; however, in a non-cylindrical aortic root, these directions may not align with these directions.

It has been shown that the aortic wall stress is highly related to dilation of aortic aneurysms. For example, Shang et al. [41] obtained a linear relation $\left(R^{2}=0.81\right)$ between the peak wall stress and the expansion rate of aortic aneurysms without surgery reparation. More recently, our group [8] obtained a linear relation $\left(R^{2}=0.92\right)$ between the mean max-principal stress and the dilation rate of aortic root aneurysm after surgery reparation. Bearing these in mind, we proposed that the evolution of the growth rate $\dot{v}_{1}$ is linearly dependent on $\sigma_{1}$, the max-principal component of the Cauchy stress, and the growth rate of $\dot{v}_{2}$ linearly dependent on the $\sigma_{2}$, the mid-principal component of the Cauchy stress. As mentioned in Sec. 2.1, the thickness of the aortic wall is not available and thus we assume that the thickness remains between Post1 and Post2. The growth evolution laws can be summarized as

$$
\begin{aligned}
& \dot{v}_{1}=\alpha_{1}\left(\sigma_{1}-\sigma_{1 c}\right), \\
& \dot{v}_{2}=\alpha_{2}\left(\sigma_{2}-\sigma_{2 c}\right), \\
& \dot{v}_{3}=0
\end{aligned}
$$


medRxiv preprint doi: https://doi.org/10.1101/2021.09.30.21264318; this version posted October 1, 2021. The copyright holder for this preprint (which was not certified by peer review) is the author/funder, who has granted medRxiv a license to display the preprint in perpetuity. All rights reserved. No reuse allowed without permission.

where $\left\{\alpha_{i}, \sigma_{i c}\right\}(i=1,2)$ are growth parameters. The parameters $\sigma_{i c}(i=1,2)>0$ can be regarded as the critical trigger stress for the growth, i.e. the growth is triggered when the stress $\sigma_{i}$ is greater than $\sigma_{i c}$ and there is no growth when the stress $\sigma_{i}$ is less than $\sigma_{i c}$. The true stress subtracted by the critical trigger stress yields the pure growth stress which contribute to the growth.

The UFD model and growth evolution law were implemented into the UMAT user-defined material subroutine of the Abaqus FEA 2020 (SIMULIA, Providence, RI). A numerical approximation scheme $[42,43]$ was applied to calculated the tangent modulus tensor. The implemented model was applied to simulate the growth of the aortic root from Post 1 to Post2. The growth parameters $\left\{\alpha_{i}, \sigma_{i c}\right\}$ for each patient were obtained by an optimization procedure based on the aortic root geometries at Post1 and Post2, which will be explained detail in the next section.

\subsection{Growth Simulation and Optimization of Growth Parameters}

Figure 3 shows the flow chart of the growth simulation and optimization of the growth parameters. We simulated the growth of the aortic root for each patient starting from the geometry of the aortic root of Post1 (Fig. 3a). Since the geometry of the aortic root was reconstructed based on the CT scans of the in vivo configuration under systolic pressure, applying the physiological systolic pressure directly on the in vivo geometry would obtain inaccurate strain and stress. Instead, the FE simulation should start from the zero-pressured geometry. We used the improved backward displacement method [44] to obtain the zero-pressured geometry of the aortic root of Post1 (Fig. $3 b)$. 

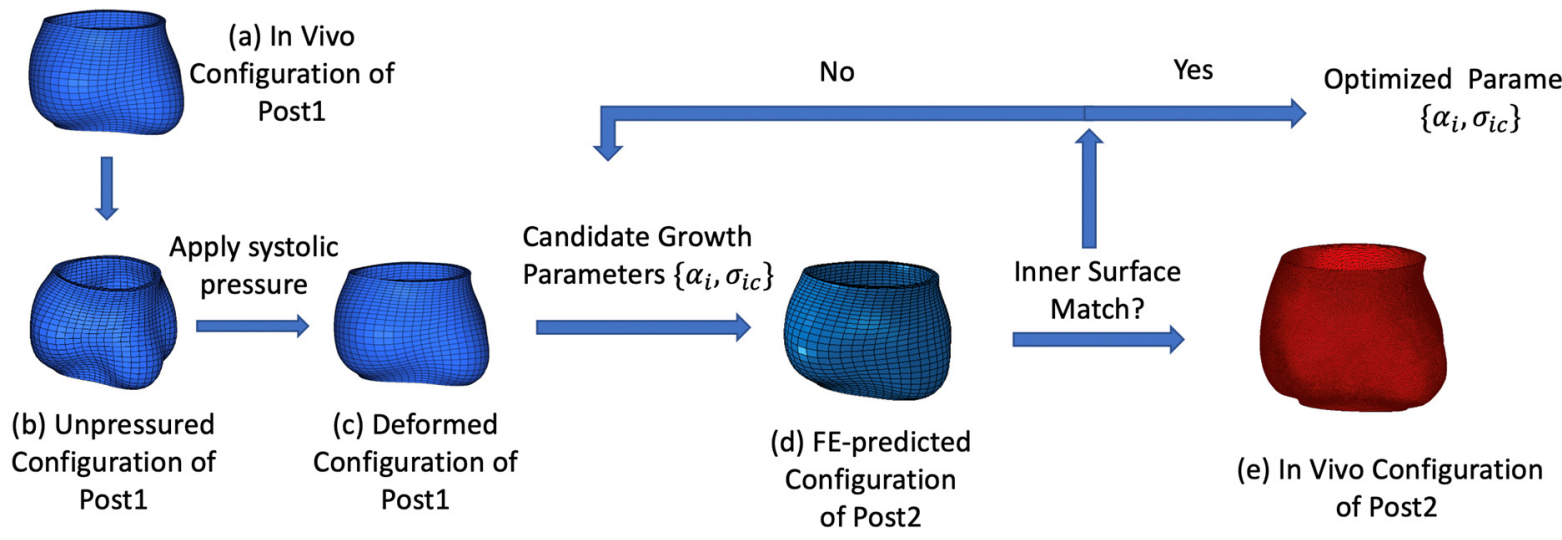

Fig 3. Flow chart of the growth simulation and optimization of growth parameters.

Based on the zero-pressured geometry of the aortic root of Post1, the finite element (FE) simulation of the growth was performed in two steps. In the first step, the patient-specific systolic pressure was applied to the inner surface of the zero-pressured geometry of the aortic root of Post1 to obtain the stress and strain fields (Fig. 3c). During the first step, there is no growth for the aortic tissue. In the second step, the growth process was activated with a group of candidate growth parameters and the growth stretch was calculated following the growth laws in Eqs. (8) and (9), based on the stress field obtained from the first step. The growth process was stopped when the growth period reached the time-point Post2 and the FE-predicted configuration of the aortic root at Post 2 was obtained (Fig. 2d). The growth parameters $\left\{\alpha_{i}, \sigma_{i c}\right\}$ was tuned until the inner surface of the FE-predicted configuration of Post2 matched the in vivo inner surface (Fig. 3e) of Post2 for the aortic root.

Specifically, the method of least squares was applied to match the FE-predicted and in vivo root inner surface of Post2. We define the node-to-surface distance between a mesh node $\mathbf{X}$ of the predicted root inner surface (extracted from Fig. 3d) and the triangle mesh $\Omega$ of the in vivo root inner surface of Post2 (Fig. 3e) as 


$$
d(\mathbf{X}, \Omega)=\min _{\mathbf{Y} \in \Omega}\|\mathbf{Y}-\mathbf{X}\|
$$

where $\mathbf{X}$ is the coordinate vector of the node, $\mathbf{Y}$ is the coordinate vector of a node on the mesh surface $\Omega$, and the operator $\|\mathbf{Z}\|$ represents the 3D Euclidean norm of an arbitrary vector $\mathbf{Z}$. The value of $d(\mathbf{X}, \Omega)$ gradually converges to a specific value with the increasing mesh density (decreasing mesh size) of $\Omega$. In this study, the distance converging mesh size of $\Omega$ was around 0.3 mm. The growth parameters $\left\{\alpha_{i}, \sigma_{i c}\right\}$ was optimized by minimizing the sum of the squares of the node-to-surface distance between the FE-predicted and in vivo root inner surface.

We implemented the optimization procedure based on the function lsqnonlin in MATLAB 2018b (MathWorks, Natick, MA). The FE simulations were performed by Abaqus FEA 2020 (SIMULIA, Providence, RI) using a cluster server (Partnership for an Advanced Computing Environment (PACE) at the Georgia Institute of Technology). The local optimization MATLAB program needs to communicate with the PACE server, including uploading files to, locally submitting jobs to, and downloading result files from the server. The uploading and downloading of files were realized by the python version of SFTP (Pysftp, https://pypi.org/project/pysftp/), and the paramiko (http://www.paramiko.org/) was used to locally submitting jobs to the server.

The root inner surface of Post1 before growth is enclosed inside of the root inner surface of Post2 (Fig. 4). Part of the root surface of Post1 could grow outside of the root surface of Post2 while other parts may still remain enclosed inside by the surface of Post 2 after the growth. In order to reflect the relative position of a node on the root inner surface of Post1 after growth to the root inner surface of Post2, we defined another distance parameter with a sign as

$$
d_{s}=\operatorname{sign}(\mathbf{X}, \Omega) d(\mathbf{X}, \Omega)
$$


medRxiv preprint doi: https://doi.org/10.1101/2021.09.30.21264318; this version posted October 1, 2021. The copyright holder for this preprint (which was not certified by peer review) is the author/funder, who has granted medRxiv a license to display the preprint in perpetuity.

All rights reserved. No reuse allowed without permission.

where $d(\mathbf{X}, \Omega)$ is given in Eq. (9), with $\operatorname{sign}(\mathbf{X}, \Omega)=1$ when $\mathbf{X}$ located inside the surface $\Omega$ and $\operatorname{sign}(\mathbf{X}, \Omega)=-1$ when $\mathbf{X}$ located outside the surface $\Omega$.

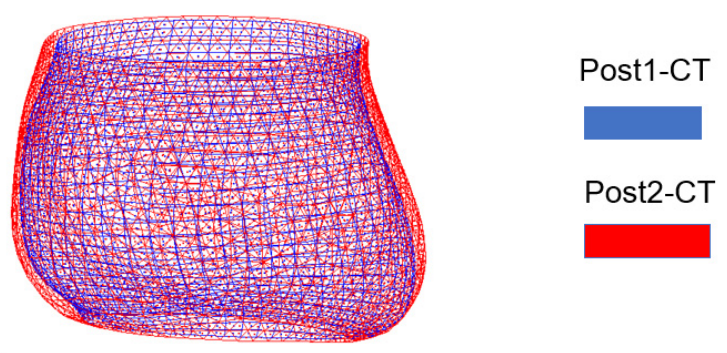

Fig 4. In vivo geometries of the aortic root for a representative patient (P1) at two follow-up time points post-surgery (Post1 and Post2), reconstructed from the clinical CT images.

\section{Results}

\subsection{Optimization Procedure and Optimized Growth Parameters}

Figure 5a shows the comparison between the FE-predicted geometry of Post2 (growth from Post1, Post1-Growth) at the first iteration and Post2 from CT, for the aortic root of a representative patient (P1). The corresponding in vivo geometries of Post1 and Post2 from CT have been shown in Fig. 4. The results in Figure 5a indicate that the growth from Post1 is too much, with the mean node-to-surface distance between Post1-Growth and Post2-CT to be $-0.62 \mathrm{~mm}$, the negative sign of the distance indicating that the overall surface of Post1 has grown outside the in vivo surface of Post 2. The candidate growth parameters were then tuned and the mean node-to-surface distance between Post1-Growth and Post2-CT reduced (in the sense of absolute value) gradually to the final value of $+0.09 \mathrm{~mm}$ (Fig. 5b). Similar results were obtained for patients P2-P4 during the optimization process. 


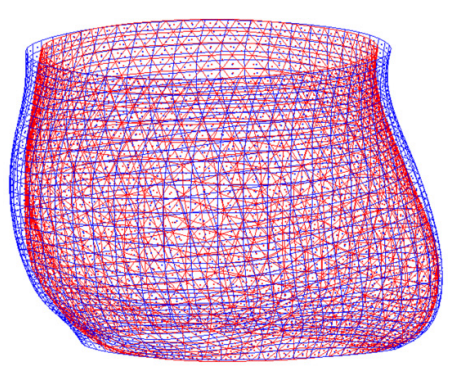

(a): Geometries of Post1-Growth at 1 st iteration and Post2-CT

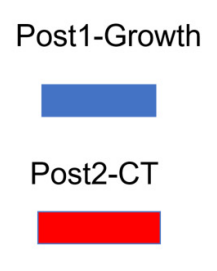

(b): Geometries of Post1-Growth at last iteration and Post2-CT

Fig 5. (a) Comparison between FE-predicted geometry of Post 2 (growth from Post1, Post1Growth) at the first iteration and in vivo geometry of Post2 from CT (Post2-CT), for a representative patient (P1); (b) comparison between FE-predicted geometry of Post2 (Post1Growth) at the last iteration and Post2-CT.

The mean node-to-surface distance between the in vivo inner surface of Post1 and Post2 for the aortic root of the 4 patients (P1-P4) ranges from $+0.79 \mathrm{~mm}$ to $+1.38 \mathrm{~mm}$ (Table 3 ). The mean node-to-surface distance between the FE-predicted inner surface of Post2 (growth from Post1) with the optimized growth parameters (Table 4) and the in vivo geometry Post2, ranging from -0.04 to $0.09 \mathrm{~mm}$. For all the patients, the value of $\alpha_{1}$ is greater than $\alpha_{2}$, and the value of $\sigma_{1 c}$ is less than $\sigma_{2 c}$.

Table 3: Mean \pm standard deviation (mean \pm std) of the node-to-surface distance between the in vivo geometries of Post1 and Post2 from the CT images (Post1-CT \& Post2-CT) for the aortic root of the 4 patients (P1-P4), and the node-to-surface distance between predicted geometry of Post 2 based on growth from Post1 (Post1-Growth) and in vivo geometry of Post2-CT. A negative mean distance (e.g., P3 and P4) between Post1-Growth and Post2-CT represents the overall root surface of Post1-Growth grows outside of the root surface of Post2-CT. The corresponding optimized growth parameters are listed in Table 4.

\begin{tabular}{|c|c|c|}
\hline Distance (mm) & Post1-CT\& Post2-CT (mean \pm std) & Post1-Growth \& Post2-CT (mean \pm std) \\
\hline P1 (P13) & $0.79 \pm 0.40$ & $0.09 \pm 0.39$ \\
\hline P2 (P07) & $1.11 \pm 0.52$ & $0.08 \pm 0.63$ \\
\hline P3 (P03) & $1.38 \pm 0.77$ & $-0.02 \pm 0.71$ \\
\hline P4 (P16) & $1.22 \pm 0.97$ & $-0.04 \pm 0.93$ \\
\hline
\end{tabular}


medRxiv preprint doi: https://doi.org/10.1101/2021.09.30.21264318; this version posted October 1, 2021. The copyright holder for this preprint (which was not certified by peer review) is the author/funder, who has granted medRxiv a license to display the preprint in perpetuity.

All rights reserved. No reuse allowed without permission.

Table 4: Optimized growth parameters in Eq. (9) for the aortic root of the 4 patients (P1-P4), corresponding to the predicted results of Post2 based on the growth from Post1 (Post1-Growth) in Table 3 .

\begin{tabular}{|c|c|c|c|c|}
\hline & $\alpha_{1}(1 /[\mathrm{MPa} \cdot \mathrm{Mon}])$ & $\alpha_{2}(1 /[\mathrm{MPa} \cdot \mathrm{Mon}])$ & $\sigma_{1 c}(\mathrm{kPa})$ & $\sigma_{2 c}(\mathrm{kPa})$ \\
\hline P1 (P13) & 0.0119 & 0.0045 & 82.5 & 290.0 \\
\hline P2 (P07) & 0.0048 & 0.0015 & 157.1 & 240.7 \\
\hline P3 (P03) & 0.0114 & 0.0065 & 38.0 & 216.6 \\
\hline P4 (P16) & 0.0025 & 0.0020 & 23.2 & 168.0 \\
\hline Average & 0.0077 & 0.0036 & 75.2 & 228.8 \\
\hline
\end{tabular}

\subsection{Prediction of P5 based on Parameters of P1-P4}

The aortic root of P5 grows mildly from Post1 to Post2 with the mean and std node-tosurface distance to be $0.85 \pm 0.51 \mathrm{~mm}$. The comparison between the predicted geometry of Post 2 (Post1-Growth), based on the average value of the optimized growth parameters of P1-P4 in Table 4, and Post2-CT suggests a good match between the predicted and in vivo geometries of Post2, with the mean node-to-surface distance between Post1-Growth and Post2-CT to be $-0.17 \pm$ $0.58 \mathrm{~mm}$ (Fig. 6).

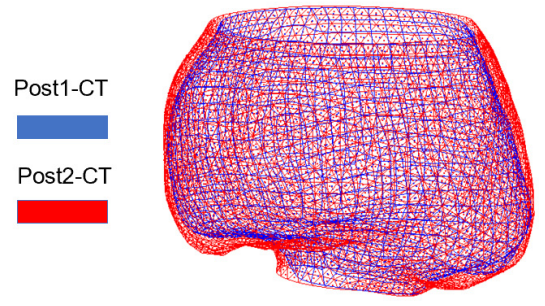

(a): Geometries of Post1-CT and Post2-CT
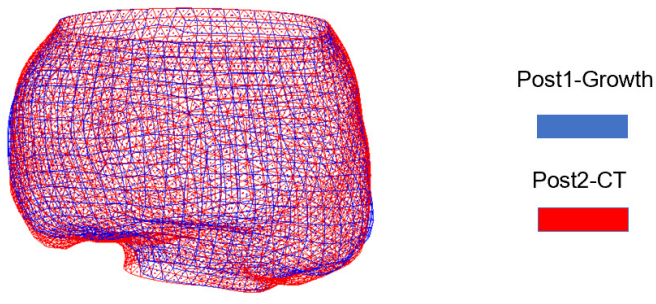

(b): Geometries of Post1-Growth and Post2-CT

Fig 6. (a) Comparison between the in vivo geometries of Post 1 from CT (Post1-CT) and Post 2 from CT (Post2-CT) for the aortic root of P5; (b) comparison between the predicted geometry of Post2 (growth from Post1, Post1-Growth) and Post2-CT. 
medRxiv preprint doi: https://doi.org/10.1101/2021.09.30.21264318; this version posted October 1, 2021. The copyright holder for this preprint (which was not certified by peer review) is the author/funder, who has granted medRxiv a license to display the preprint in perpetuity.

All rights reserved. No reuse allowed without permission.

\subsection{Aortic Root Wall Stress}

We also obtained the wall stress of the aortic root of Post 2 based on the predicted and in vivo geometries. Figure 7 showed the max-principal stress field of the aortic root of Post 2 for a representative patient $(\mathrm{P} 1)$, which suggests that the overall stress distribution follows similar pattern for results based the predicted (Fig. 7a) and in vivo (Fig. 7b) geometries. Table 5 presented the mean and peak values of the max-principal stress of Post2 based on the predicted and in vivo geometries for the five patients (P1-P5). The stress based on predicted geometry agrees well with that based on the in vivo geometry, with an average difference of $-3.83 \%$ for the mean value and 4.12\% average difference for the peak value.

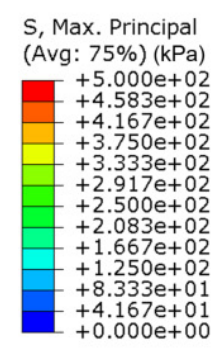

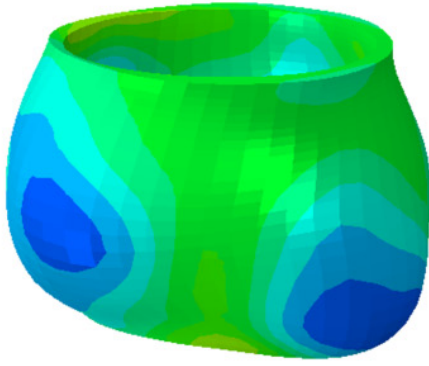

(a)

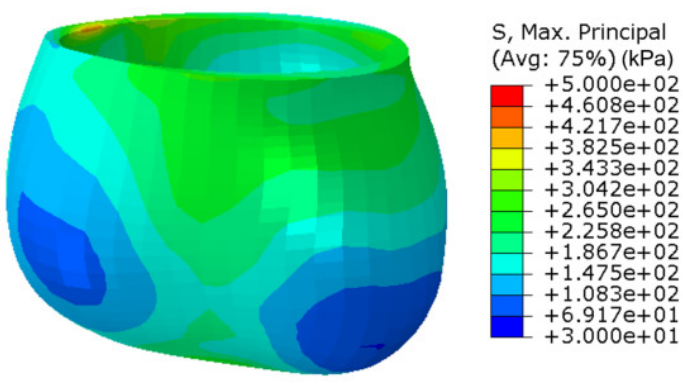

(b)

Fig 7. Max-principal stress field of the aortic root of Post2 for a representative patient (P1): (a) results based on the predicted geometry; (b) results based on in vivo geometry. The stress distributions follows similar pattern. 
medRxiv preprint doi: https://doi.org/10.1101/2021.09.30.21264318; this version posted October 1, 2021. The copyright holder for this preprint (which was not certified by peer review) is the author/funder, who has granted medRxiv a license to display the preprint in perpetuity.

All rights reserved. No reuse allowed without permission.

Table 5: Mean and peak values of the max-principal stress of Post2 based on the predicted and in vivo geometries for the five patients (P1-P5).

\begin{tabular}{|c|c|c|c|c|c|c|}
\hline \multirow{2}{*}{} & \multicolumn{3}{|c|}{ Mean Stress (kPa) } & \multicolumn{3}{c|}{ Peak Stress (kPa) } \\
\cline { 2 - 7 } & Predicted & In Vivo & Difference & Predicted & In Vivo & Difference \\
\hline P1-Post2 & 163.01 & 164.88 & $-1.13 \%$ & 262.11 & 266.56 & $-1.67 \%$ \\
\hline P2-Post2 & 202.75 & 224.04 & $-9.50 \%$ & 287.56 & 315.68 & $-8.91 \%$ \\
\hline P3-Post2 & 181.82 & 184.38 & $-1.39 \%$ & 321.14 & 359.22 & $-10.60 \%$ \\
\hline P4-Post2 & 182.63 & 202.5 & $-9.81 \%$ & 278.97 & 293.77 & $-5.04 \%$ \\
\hline P5-Post2 & 157.52 & 148.11 & $6.35 \%$ & 384.35 & 359.99 & $6.77 \%$ \\
\hline Average & 177.546 & 184.782 & $-3.92 \%$ & 306.826 & 319.044 & $-3.83 \%$ \\
\hline
\end{tabular}

\section{Discussions}

We developed a novel computational growth framework for biological tissues based on the unified-fiber-distribution (UFD) model and kinematic growth approach, in which growth is governed by the two in-plane principal components of the Cauchy stress. The UFD model [20] considers the fiber distribution in aortic tissues as a unified distribution which is expected to be more physically consistent, with the real fiber distribution in aortic tissues, than separating the fiber distributions into two/several fiber families. For the kinematic growth evolution law, four growth parameters $\left\{\alpha_{1}, \alpha_{2}, \sigma_{1 c}, \sigma_{2 c}\right\}$ were used in Eq. (9). The parameters $\left\{\alpha_{1}, \alpha_{2}\right\}$ control the growth rate under specific stress conditions, and the parameters $\left\{\sigma_{1 c}, \sigma_{2 c}\right\}$ represent the critical trigger value of the Cauchy stress that could induce the growth. For instance, for the optimized parameters of P1 in Table 4, the value of $\sigma_{1 c}=82.5 \mathrm{kPa}$ indicates that there will be no growth in 1 direction when $\sigma_{1}$ is less than $82.5 \mathrm{kPa}$, and the value of $\alpha_{1}=0.0119[\mathrm{MPa} \cdot \mathrm{Mon}]^{-1}$ suggests that the growth stretch will be $0.119 \%$ per month under the pure growth stress value of $100 \mathrm{kPa}$ (Cauchy stress subtracting the growth trigger stress). 
medRxiv preprint doi: https://doi.org/10.1101/2021.09.30.21264318; this version posted October 1, 2021. The copyright holder for this preprint (which was not certified by peer review) is the author/funder, who has granted medRxiv a license to display the preprint in perpetuity.

All rights reserved. No reuse allowed without permission.

As mentioned before in Sec. 2.2.2, the principal stresses $\sigma_{1}$ and $\sigma_{2}$ are along the circumferential and axial directions, respectively, for a perfect cylindrical tube under inner pressure loading. The geometry of the aortic root (e.g, Fig. 1c) is a cylinder-like tube, and the principal stresses $\sigma_{1}$ and $\sigma_{2}$ in the aortic root are approximately along the circumferential and axial directions, respectively. The value of the optimized growth parameter $\alpha_{1}$ is greater than that of $\alpha_{2}$ for all patients (Table 4), which suggests that the growth rate in the circumferential direction is larger than that in axial direction under the same pure growth stress. The optimized value of $\sigma_{1 c}$ is smaller than that of $\sigma_{2 c}$ for all patients indicates that the growth in the circumferential direction is easier to be triggered than that in the axial direction.

We used the growth parameters of P1-P4 to predict the growth of the aortic root of P5, which illustrated the possibility of predicting growth of new patients based on parameters of existing patients. It is possible that predictions of growth for other new patients based on the database of $\mathrm{P} 1-\mathrm{P} 4$ are not as accurate as that of $\mathrm{P} 5$, since the current database contains a rather limited number of patients. The database of the growth parameters will be expanded with follow-up CT images of more patients being accumulated. Vande Geest et al. [45] showed that the patient-specific material property of aortic wall (e.g., wall strength) is possible to be estimated from existing database depending on clinical factors such as age, gender, family history, etc. The patient-specific growth parameters may also depend on these clinical factors. The parameters for new patients estimated based on the approach of age-gender-match from a larger parameter database may produce more accurate prediction of the growth.

Long-time consuming is one of the most distinguishing features for optimization problems, since the optimization process usually requires multiple iterations in order to obtain the optimized solution. The optimization of the growth parameters in this study is even more complex because 
medRxiv preprint doi: https://doi.org/10.1101/2021.09.30.21264318; this version posted October 1, 2021. The copyright holder for this preprint (which was not certified by peer review) is the author/funder, who has granted medRxiv a license to display the preprint in perpetuity.

All rights reserved. No reuse allowed without permission.

the finite element (FE) simulation result is needed for each iteration during the optimization procedure. We used a combined technique which includes the local PC for optimization procedure and the cluster server to perform the FE simulation. Comparing to running all the computations with a local PC, such kind of combined technique could reduce the costing time in two way: 1) the FE simulation performed on the cluster server is significantly faster than that on a local PC; 2) the optimization for different patients could be performed simultaneously since a cluster server has less limited (or unlimited) CPU resources.

There are several limitations of this study. First, the in vivo thickness of the aortic root was not available from the CT images, and thus the potential growth in the radial direction from Post1 to Post 2 was not considered in our simulation. As shown by others, the time rate of change of radial versus in-plane growth can be an important factor in the growth rate of aneurysms [46-48] and should be a topic of future work. In vivo thickness of the aortic wall may be obtained based on the method in Elefteriades et al. [49] when both contrast and non-contrast CT scans are available. Second, although the patient-specific growth parameters were obtained from the optimization procedure, only one set of hyperelastic material properties derived from experimental ex vivo data of human aortic aneurysm tissue were used for all the patients in this study. Patient-specific elastic material properties may be obtained by inverse methods $[50,51]$ when two-phase CT images under different pressure loadings are available. Finally, we only have five patients with CT images available at two follow-up time points for the growth simulation. Future studies should include larger cohort of patients with more CT data being accumulated.

\section{Conclusions}

In this study, we developed a novel computational growth framework for biological tissues and applied it to simulate the growth of the aortic root aneurysm repaired by the V-shape surgery. 
medRxiv preprint doi: https://doi.org/10.1101/2021.09.30.21264318; this version posted October 1, 2021. The copyright holder for this preprint (which was not certified by peer review) is the author/funder, who has granted medRxiv a license to display the preprint in perpetuity.

All rights reserved. No reuse allowed without permission.

Particularly, the unified-fiber-distribution (UFD) model was applied to describe the hyerelastic deformation of the aortic tissue. A novel kinematic growth evolution law was proposed based on existing observations that the growth rate is linearly dependent on the wall stress. Moreover, we also obtained patient-specific geometries of the aortic root aneurysm post-surgery at two followup time points (Post1 and Post2) for 5 patients, based on clinical CT images. The novel computational growth framework was implemented into the UMAT user subroutine of the Abaqus FEA, and applied to model the growth of the aortic root from Post1 to Post2. Patient-specific growth parameters were obtained by an optimization procedure. The predicted geometry and stress of the aortic root at Post2 agree well with the in vivo results. The novel computational growth framework and the optimized growth parameters could be applied to predict the growth of repaired aortic root aneurysms for new patients.

\section{Acknowledgment}

H. Dong thanks lab members Courtney Huynh, Samuel Li, and Kristen Riess for assistance in image segmentation, mesh creation and finite element simulation. This study is in part supported by American Heart Association (AHA) 18TPA34230083.

\section{Conflict of Interest}

Dr. Wei Sun is a co-founder and serves as the Chief Scientific Advisor of Dura Biotech. He has received compensation and owns equity in the company. Dr. Elefteriades is Principal of CoolSpine serves on the Data and Safety Monitoring Board of Vascutek, and is a consultant for CryoLife. The other authors declare no conflict of interest. 


\section{Appendix: Resolution of CT images}

The in-plane spatial resolution of the CT images of the five patients (P1-P5) is between $0.37 \times 0.37 \mathrm{~mm}$ and $0.96 \times 0.96 \mathrm{~mm}$, with the slice thickness ranging from 0.30 to $1.00 \mathrm{~mm}$. The details of the CT images resolution for each patient were listed in Table A1.

Table A1: In-plane resolution and slice thickness of CT images of Post1 and Post2 for aortic root of P1-P5.

\begin{tabular}{|c|c|c|c|c|}
\hline Patient & $\begin{array}{c}\text { In-plane resolution } \\
\text { of Post1 }(\mathrm{mm})\end{array}$ & $\begin{array}{c}\text { Slice thickness of } \\
\text { Post1 }(\mathrm{mm})\end{array}$ & $\begin{array}{c}\text { In-plane resolution } \\
\text { of Post2 }(\mathrm{mm})\end{array}$ & $\begin{array}{c}\text { Slice thickness of } \\
\text { Post2 }(\mathrm{mm})\end{array}$ \\
\hline P1 & $0.49 \times 0.49$ & 0.63 & $0.71 \times 0.71$ & 1.00 \\
\hline P2 & $0.63 \times 0.63$ & 0.63 & $0.96 \times 0.96$ & 0.63 \\
\hline P3 & $0.69 \times 0.69$ & 0.30 & $0.69 \times 0.69$ & 0.30 \\
\hline P4 & $0.78 \times 0.78$ & 0.63 & $0.74 \times 0.74$ & 0.63 \\
\hline P5 & $0.67 \times 0.67$ & 0.30 & $0.37 \times 0.37$ & 0.60 \\
\hline
\end{tabular}

\section{References}

[1] V. Pressler, J.J. McNamara, Aneurysm of the thoracic aorta: review of 260 cases, The Journal of thoracic and cardiovascular surgery 89(1) (1985) 50-54.

[2] M.A. Coady, J.A. Rizzo, G.L. Hammond, D. Mandapati, U. Darr, G.S. Kopf, J.A. Elefteriades, What is the appropriate size criterion for resection of thoracic aortic aneurysms?, The Journal of thoracic and cardiovascular surgery 113(3) (1997) 476-491.

[3] M.A. Coady, J.A. Rizzo, J.A. Elefteriades, Developing surgical intervention criteria for thoracic aortic aneurysms, Cardiology clinics 17(4) (1999) 827-839.

[4] R.R. Davies, A. Gallo, M.A. Coady, G. Tellides, D.M. Botta, B. Burke, M.P. Coe, G.S. Kopf, J.A. Elefteriades, Novel measurement of relative aortic size predicts rupture of thoracic aortic aneurysms, The Annals of thoracic surgery 81(1) (2006) 169-177.

[5] G.T. Stavridis, R.S. Downey, M.W. Gerdisch, G.C. Hughes, M.J. Jasinski, J.S. Rankin, D. Mazzitelli, D. Aicher, T. Fischlein, Y.-H. Choi, Aortic valve repair for tri-leaflet aortic insufficiency associated with asymmetric aortic root aneurysms, Annals of cardiothoracic surgery 8(3) (2019) 426.

[6] T.E. David, C.M. Feindel, G.D. Webb, J.M. Colman, S. Armstrong, M. Maganti, Long-term results of aortic valve-sparing operations for aortic root aneurysm, The Journal of Thoracic and Cardiovascular Surgery 132(2) (2006) 347-354.

[7] J.A. Elefteriades, S. Peterss, N. Nezami, G. Gluck, W. Sun, M. Tranquilli, B.A. Ziganshin, V-shape noncoronary sinus remodeling in ascending aortic aneurysm and aortic root ectasia, The Journal of thoracic and cardiovascular surgery 154(1) (2017) 72-76.

[8] H. Dong, M. Liu, T. Qin, L. Liang, B. Ziganshin, H. Ellauzi, M. Zafar, S. Jang, J. Elefteriades, W. Sun, Engineering Analysis of Aortic Wall Stress and Root Dilatation in the V-shape Surgery for Treatment of 
medRxiv preprint doi: https://doi.org/10.1101/2021.09.30.21264318; this version posted October 1, 2021. The copyright holder for this preprint (which was not certified by peer review) is the author/funder, who has granted medRxiv a license to display the preprint in perpetuity.

All rights reserved. No reuse allowed without permission.

Ascending Aortic Aneurysms, submitted to Interactive CardioVascular and Thoracic Surgery, Under Review (2020).

[9] W. Lin, M. Iafrati, R. Peattie, L. Dorfmann, Growth and remodeling with application to abdominal aortic aneurysms, Journal of Engineering Mathematics 109(1) (2018) 113-137.

[10] S.J. Mousavi, S. Farzaneh, S. Avril, Patient-specific predictions of aneurysm growth and remodeling in the ascending thoracic aorta using the homogenized constrained mixture model, Biomech Model Mechanobiol 18(6) (2019) 1895-1913.

[11] A. Ghavamian, S.J. Mousavi, S. Avril, Computational study of growth and remodeling in Ascending Thoracic Aortic Aneurysms considering variations of Smooth Muscle Cell basal tone, Frontiers in Bioengineering and Biotechnology 8 (2020).

[12] M. Farsad, S. Zeinali-Davarani, J. Choi, S. Baek, Computational growth and remodeling of abdominal aortic aneurysms constrained by the spine, Journal of biomechanical engineering 137(9) (2015) 091008.

[13] J. Humphrey, K. Rajagopal, A constrained mixture model for growth and remodeling of soft tissues, Mathematical models and methods in applied sciences 12(03) (2002) 407-430.

[14] E.K. Rodriguez, A. Hoger, A.D. McCulloch, Stress-dependent finite growth in soft elastic tissues, Journal of biomechanics 27(4) (1994) 455-467.

[15] C.M. Witzenburg, J.W. Holmes, A comparison of phenomenologic growth laws for myocardial hypertrophy, J Elasticity 129(1) (2017) 257-281.

[16] A.R. Akintunde, K.S. Miller, Evaluation of microstructurally motivated constitutive models to describe age-dependent tendon healing, Biomech Model Mechanobiol 17(3) (2018) 793-814.

[17] D. Ambrosi, F. Mollica, On the mechanics of a growing tumor, International journal of engineering science 40(12) (2002) 1297-1316.

[18] M. Eskandari, W.G. Kuschner, E. Kuhl, Patient-specific airway wall remodeling in chronic lung disease, Annals of biomedical engineering 43(10) (2015) 2538-2551.

[19] M. Soleimani, N. Muthyala, M. Marino, P. Wriggers, A novel stress-induced anisotropic growth model driven by nutrient diffusion: Theory, FEM implementation and applications in bio-mechanical problems, Journal of the Mechanics and Physics of Solids 144 (2020) 104097.

[20] H. Dong, W. Sun, A novel hyperelastic model for biological tissues with planar distributed fibers and a second kind of Poisson effect, Journal of the Mechanics and Physics of Solids 151 (2021) 104377.

[21] T. Qin, A. Caballero, W. Mao, B. Barrett, N. Kamioka, S. Lerakis, W. Sun, The role of stress concentration in calcified bicuspid aortic valve, Journal of the Royal Society Interface 17(167) (2020) 20190893.

[22] T. Qin, A. Caballero, R.T. Hahn, R. McKay, W. Sun, Computational Analysis of Virtual Echocardiographic Assessment of Functional Mitral Regurgitation for Validation of Proximal Isovelocity Surface Area Methods, Journal of the American Society of Echocardiography (2021).

[23] L. Liang, M. Liu, C. Martin, J.A. Elefteriades, W. Sun, A machine learning approach to investigate the relationship between shape features and numerically predicted risk of ascending aortic aneurysm, Biomech Model Mechanobiol (2017).

[24] G.A. Holzapfel, T.C. Gasser, R.W. Ogden, A new constitutive framework for arterial wall mechanics and a comparative study of material models, Journal of elasticity and the physical science of solids 61(1) (2000) 1-48.

[25] M. Liu, H. Dong, X. Lou, G. lannucci, E.P. Chen, B.G. Leshnower, W. Sun, A Novel Anisotropic Failure Criterion With Dispersed Fiber Orientations for Aortic Tissues, Journal of Biomechanical Engineering 142(11) (2020) 111002.

[26] S. Pejcic, S.M.A. Hassan, D.E. Rival, G. Bisleri, Characterizing the mechanical properties of the aortic wall, Vessel Plus 3 (2019). 
medRxiv preprint doi: https://doi.org/10.1101/2021.09.30.21264318; this version posted October 1, 2021. The copyright holder for this preprint (which was not certified by peer review) is the author/funder, who has granted medRxiv a license to display the preprint in perpetuity. All rights reserved. No reuse allowed without permission.

[27] M. Liu, L. Liang, Y. Ismail, H. Dong, X. Lou, G. Iannucci, E.P. Chen, B.G. Leshnower, J.A. Elefteriades, W. Sun, Computation of a probabilistic and anisotropic failure metric on the aortic wall using a machine learning-based surrogate model, Computers in Biology and Medicine (2021) 104794.

[28] A. Puck, H. Schürmann, Failure analysis of FRP laminates by means of physically based phenomenological models, Failure criteria in fibre-reinforced-polymer composites, Elsevier2004, pp. 832876.

[29] H. Dong, J. Wang, B. Karihaloo, An improved Puck's failure theory for fibre-reinforced composite laminates including the in situ strength effect, Composites science and technology 98 (2014) 86-92.

[30] H. Dong, J. Wang, A criterion for failure mode prediction of angle-ply composite laminates under inplane tension, Composite Structures 128 (2015) 234-240.

[31] H. Dong, Z. Li, J. Wang, B. Karihaloo, A new fatigue failure theory for multidirectional fiber-reinforced composite laminates with arbitrary stacking sequence, International Journal of Fatigue 87 (2016) 294-300. [32] R. Häsä, S. Pinho, Failure mechanisms of biological crossed-lamellar microstructures applied to synthetic high-performance fibre-reinforced composites, Journal of the Mechanics and Physics of Solids 125 (2019) 53-73.

[33] A.J. Schriefl, G. Zeindlinger, D.M. Pierce, P. Regitnig, G.A. Holzapfel, Determination of the layerspecific distributed collagen fibre orientations in human thoracic and abdominal aortas and common iliac arteries, Journal of the Royal Society Interface 9(71) (2012) 1275-1286.

[34] T.C. Gasser, R.W. Ogden, G.A. Holzapfel, Hyperelastic modelling of arterial layers with distributed collagen fibre orientations, Journal of the royal society interface 3(6) (2006) 15-35.

[35] G.A. Holzapfel, Nonlinear solid mechanics: A continuum approach for engineering science, John Wiley \& Sons, Ltd2000.

[36] H. Dong, J. Wang, M. Rubin, A nonlinear cosserat interphase model for residual stresses in an inclusion and the interphase that bonds it to an infinite matrix, International Journal of Solids and Structures 62 (2015) 186-206.

[37] H. Dong, Z. Wang, T.C. O'Connor, A. Azoug, M.O. Robbins, T.D. Nguyen, Micromechanical models for the stiffness and strength of UHMWPE macrofibrils, Journal of the Mechanics and Physics of Solids 116 (2018) 70-98.

[38] H. Dong, M. Liu, C. Martin, W. Sun, A residual stiffness-based model for the fatigue damage of biological soft tissues, Journal of the Mechanics and Physics of Solids 143 (2020) 104074.

[39] H. Dong, Y. Hu, Harnessing fluid pre-pressure to tune the properties of phononic crystals, Extreme Mechanics Letters 34 (2020) 100582.

[40] C. Martin, W. Sun, J. Elefteriades, Patient-specific finite element analysis of ascending aorta aneurysms, American Journal of Physiology-Heart and Circulatory Physiology 308(10) (2015) H1306H1316.

[41] E.K. Shang, D.P. Nathan, S.R. Sprinkle, S.C. Vigmostad, R.M. Fairman, J.E. Bavaria, R.C. Gorman, J.H. Gorman III, K.B. Chandran, B.M. Jackson, Peak wall stress predicts expansion rate in descending thoracic aortic aneurysms, The Annals of thoracic surgery 95(2) (2013) 593-598.

[42] H. Liu, W. Sun, Computational efficiency of numerical approximations of tangent moduli for finite element implementation of a fiber-reinforced hyperelastic material model, Computer methods in biomechanics and biomedical engineering 19(11) (2016) 1171-1180.

[43] H. Liu, M. Zhang, M. Liu, C. Martin, Z. Cai, W. Sun, Finite element simulation of three dimensional residual stress in the aortic wall using an anisotropic tissue growth model, Journal of the mechanical behavior of biomedical materials 92 (2019) 188-196.

[44] L. Liang, M. Liu, C. Martin, J.A. Elefteriades, W. Sun, A machine learning approach to investigate the relationship between shape features and numerically predicted risk of ascending aortic aneurysm, Biomech Model Mechanobiol 16(5) (2017) 1519-1533. 
medRxiv preprint doi: https://doi.org/10.1101/2021.09.30.21264318; this version posted October 1, 2021. The copyright holder for this preprint (which was not certified by peer review) is the author/funder, who has granted medRxiv a license to display the preprint in perpetuity. All rights reserved. No reuse allowed without permission.

[45] J.P. Vande Geest, D.H.J. Wang, S.R. Wisniewski, M.S. Makaroun, D.A. Vorp, Towards A Noninvasive Method for Determination of Patient-Specific Wall Strength Distribution in Abdominal Aortic Aneurysms, Annals of Biomedical Engineering 34(7) (2006) 1098-1106.

[46] S. Seyedsalehi, L. Zhang, J. Choi, S. Baek, Prior distributions of material parameters for Bayesian calibration of growth and remodeling computational model of abdominal aortic wall, Journal of biomechanical engineering 137(10) (2015).

[47] E. Akkoyun, S.T. Kwon, A.C. Acar, W. Lee, S. Baek, Predicting abdominal aortic aneurysm growth using patient-oriented growth models with two-step Bayesian inference, Computers in biology and medicine 117 (2020) 103620.

[48] E. Akkoyun, H. Gharahi, S.T. Kwon, B.A. Zambrano, A. Rao, A.C. Acar, W. Lee, S. Baek, Defining a master curve of abdominal aortic aneurysm growth and its potential utility of clinical management, Computer Methods and Programs in Biomedicine 208 (2021) 106256.

[49] J.A. Elefteriades, S.K. Mukherjee, H. Mojibian, Discrepancies in measurement of the thoracic aorta: JACC review topic of the week, Journal of the American College of Cardiology 76(2) (2020) 201-217.

[50] M. Liu, L. Liang, W. Sun, Estimation of in vivo constitutive parameters of the aortic wall using a machine learning approach, Computer methods in applied mechanics and engineering 347 (2019) 201217.

[51] M. Liu, L. Liang, W. Sun, A new inverse method for estimation of in vivo mechanical properties of the aortic wall, Journal of the mechanical behavior of biomedical materials 72 (2017) 148-158. 